$\begin{array}{ll} & \text { Etnográfica } \\ \text { etnográfica } & \text { Revista do Centro em Rede de Investigação em }\end{array}$

Antropologia

vol. $15(2) \mid 2011$

Vol. $15(2)$

\title{
Henri Junod, Usos e Costumes dos Bantu
}

\section{Omar Ribeiro Thomaz}

\section{OpenEdition \\ Journals}

\section{Electronic version}

URL: https://journals.openedition.org/etnografica/1005

DOI: 10.4000/etnografica.1005

ISSN: 2182-2891

\section{Publisher}

Centro em Rede de Investigação em Antropologia

\section{Printed version}

Date of publication: 1 June 2011

Number of pages: 405-407

ISSN: 0873-6561

Electronic reference

Omar Ribeiro Thomaz, "Henri Junod, Usos e Costumes dos Bantu", Etnográfica [Online], vol. 15 (2) I

2011, Online since 23 October 2011, connection on 10 February 2022. URL: http://

journals.openedition.org/etnografica/1005 ; DOI: https://doi.org/10.4000/etnografica.1005

\section{(c) (i) (9)}

Etnográfica is licensed under a Creative Commons Attribution-NonCommercial 4.0 International License. 
Henri Junod

\section{USOS E COSTUMES DOS BANTU}

Campinas, IFCH/Unicamp, 2009, 436 pp.

"Classic is not a book (I must stress) that necessarily possesses this or that set of qualities; it is rather a book that generations of people, urged by different reasons, read with foregoing zeal and with mysterious loyalty" (Jorge Luis Borges, "Sobre los clásicos", in Obras Completas II, Barcelona, Emecé, 1996: 151).

When dealing with the life and work of Henri Junod, Patrick Harries highlights his standing in the high ranges of the anthropological discipline, ${ }^{1}$ stressing that authors like Malinowski, Evans-Pritchard, Max Gluckman and, more recently, Adrian Hastings all remember The Life of a South African Tribe as a "masterpiece", a classic of the anthropological field after all. A unique classic, nonetheless, since it is linked to evolutionist theoretical assumptions fiercely criticized by the founders of modern anthropology and never effectively invoked back from the past in any other sense than as part of the "history of the discipline". What is the meaning, thus, of all these tributes to Junod's work by field anthropologists and ferocious critics of the pre-modern phase of the discipline? How to reassess nowadays the ethnographic work carried out by a missionary, created by someone who never gave up what he considered his primary calling, the conversion of South African natives to Christianity?

There is no doubt that The Life of a South African Tribe is a classic. It is so, although,

I Patrick Harries, Junod e as Sociedades Africanas: Impacto dos Missionários Suíços na África Austral. Maputo, Paulinas, 2007, pp. 1-2. in a rather different sense, surpassing the purpose set to it by its very author. In his view, he was recording for posterity a way of life doomed to disappear under the advance of European civilization. In which sense does it reach beyond that? His interest reaches much further than that of a historian of the discipline. The Life of $a$ South African Tribe seems to address, on one side, the diverse groups that, unified under the demonymic of Tsonga, have become the object of Junod's scrutiny ${ }^{2}$ - they seem to still regard with vivid interest his masterful work, different from the modern Nuer, who apparently are, as Sharon E. Hutchinson has noted, completely immune to the classical study performed by Evans-Pritchard about their ancestors ${ }^{3}$ - and, on the other side, the group of anthropologists and historians dedicated to assess the contemporary situation of the peoples of southern Mozambique. In what refers particularly to the anthropologists, I would dare to say that their main interest resides precisely in the kind of anthropology Junod has developed.

The Life of a South African Tribe bears all the highly praised traits of the best modern (or modernist) ethnographic works, even though it has been effectively written before modernism could have taken root in the field of social anthropology: it is rigorously assembled on the basis of a thoroughly accomplished fieldwork, and could only have been written due to the long permanence of the anthropologist/ethnographer

2 Published recently in Mozambique under the title (in Portuguese) Usos e Costumes dos Bantu (Maputo, Arquivo Histórico de Moçambique, 1996), both volumes of Junod's work have become a favorite topic of discussion among university students and an indispensable item to figure in the library of any Mozambican intelectual.

3 Cf. Sharon E. Hutchinson, Nuer Dilemmas: Coping with Money, War, and the State. Berkeley, University of California Press, 1996. 
on the field, to the deep knowledge of the native language, to the careful selection of qualified informants, accordingly prepared by the ethnographer and with whom a relationship of genuine friendship comes to be established.

If Junod's work approaches the method of what would eventually be called a modernist anthropology, it also keeps a safe distance from this method, if only to better overcome it. In many different instances Junod cuts the flow of the ethnographic prose in order to make room for reflections and information about how the Tsonga of southern Mozambique would be undergoing contemporary transformations; his comments figure not only in an introductory section or in footnotes, as would later become usual for many functionalist or structural-functionalist texts, and his notes about the ongoing changes are not restricted to his valuable annexes, they are rather scattered along the whole text. The case of polygamy is exemplary. Junod not only reflects upon the advantages and disadvantages of polygamy as an anthropologist, that is, trying to approach the native point of view, but also challenges frontally the Christian Tsonga on that thorny subject. How did they, who had undergone a radical change in their beliefs, perceive polygamy? Similarly, he does not fall short of pronouncing his own perception, based on the complex set of beliefs of an ethnographer who is at the same time a Christian missionary. We are dealing after all with a polyphonic text.

Perhaps one of the most impressive elements of Henri Junod's monograph is his assessment of Tsonga history. He strives to recover the historical dimension in the self-perception of the group, their historical relations with neighboring groups, with missionaries, soldiers, settlers, colonial agents, Englishmen, Boers and Portuguese. The Tsonga are far from fitting into a crystallized representation of Sub-Saharan African groups as projected upon many actual communities by anthropologists endorsed or not by the colonial administration. Junod's historical survey opened many doors for an anthropology interested in perceiving and describing social transformation, inspiring in particular a certain heterodox tradition of Anglo-Saxon and, even more clearly, South-African authors - such names as Isaac Shapera, Max Gluckman, Hilda Kuper, Adam Kuper, Monica Wilson, and Victor Turner, come to mind, among many others.

When reflecting upon the changes and challenges faced by the peoples of Southern Mozambique, it is strikingly evident that it was not a one-way development, that the transformation was not heading irreversibly towards adaptation to the colonial society, contrary to views held by stricter cultural evolutionist voices. The author cannot hide his surprise at the transformation that even groups of white settlers were undergoing when living side by side with indigenous groups, some of them adopting extensive elements of native traditions, rituals, uses and costumes, and polygamy comes to the forefront here again as a favorite example for the author, in a development that embodies the main fear haunting European colonialist minds established in Southern Africa: the risks of an eventual kafirization of the white settler.

In the context where Junod's work was inscribed, evolutionism was, among the many different available interpretations of cultural diversity, the most progressive. His humanism and universalism-oriented interlocutors were very far away: in the colonial context, and even in Europe, racialist ideas were hegemonic. On one side, there were those who believed that any effort directed at civilizing or evangelizing peoples living in southern African territories would bear no fruit at all: the natives would be 
racially inferior and the thirst for freedom intrinsic to the heritage of the Enlightenment would amount to no more than a cherished illusion; on the other side, were those who defended that European intervention in Africa should be limited to the promotion of an industrious working ethos among indigenous peoples, based on new forms of compulsory labor under which the natives would be condemned to perennial supervision and control by the white settlers. Evolutionism, with the whole edifice of its historical understanding that would eventually be so thoroughly criticized, still retained a crucial element inherited from Enlightenment ideas, both theoretically and practically condemned by contemporaries as something completely out of fashion and utterly out of touch with the realities of the colonial endeavor as it was regarded at the turn of the $20^{\text {th }}$ century: the idea that all human beings are equally perfectible.

However, the most fascinating aspect of Junod's work is his procedural perception of the social reality among the Tsonga. And it is from this perspective that the author establishes a real agenda for the Africanist anthropology of his time: confronting the entangled notions of individual and person; entwining basic elements of village life with encompassing structures of politics and kinship; reassessing institutes of land ownership within the conflictual process of colonial settlement; highlighting the role played by magic, witchcraft and religion in native daily life; and finally, achieving a major empirical discovery, with crucial consequences for the modern anthropological discipline, regarding the eminence of ritual life and rites of passage. In political matters, Henri Junod goes way beyond all those who preceded him, stressing that the African chief was far from being a local despot, for his power would be subject to multiple social checks and instances of control. Legitimacy in the discharge of political functions or in the exercise of political power would be rather anchored in a set of expectations and practices that would outreach the supposed transcendence of tradition.

By reading The Life of a South African Tribe today, we are presented not only to a rich image of how the Tsonga of southern Mozambique would have been and lived upon the arrival of European settlers, we are rather thrown straight into what was, and still is, a social universe in undeniable and violent transformation, a world in turmoil.

\section{Omar Ribeiro Thomaz}

Instituto de Filosofia e Ciências Humanas, Unicamp, Brazil 